Onnes Laboratory, Leyden, and Prof. F. E. Simon, professor of thermodynamics, University of Oxford; Class II (Natural and Physiological Sciences), Prof. $\mathrm{K}$. von Frisch, professor of zoology, University of Graz, and Prof. J. B. Collip, dean of the Medical Faculty, University of Western Ontario ; Class III (Social Arts), Geoffrey Crowther, editor of The Economist, London, and Dr. J. T. Bodet, director-general of Unesco; Class IV (Humanities), Dr. A. C. Andrade, director of the National Institute of Anthropology and History, Mexico.

\section{Institution of Mechanical Engineers: Honorary Members}

HoNORARY membership of the Institution of Mechanical Engineers has been conferred on Lord Dudley Gordon, for his distinguished services to the Institution and to the achievement of its objects; and on Mr. J. A. Jameson, for distinction in the practice, organization and administration of engineering. Lord Dudley Gordon is a past-president of the Institution of Mechanical Engineers. He has specialized in refrigeration and was president of the British Association of Refrigeration during 1926-29. Mr. Jameson is a director of the Anglo-Iranian Oil Co., Ltd., and during the course of his experience he made himself master of all the manifold technical aspects of petroleum exploration, exploitation, production and refining.

\section{Research and Development in Great Britain}

REPLYING to a question from Lord Samuel in the House of Lords on June 12, Lord Woolton stated that a site immediately down-river from Waterloo Bridge and facing Somerset House has been reserved for the British Science Centre by the London County Council, which is the planning authority. At this stage he could give no assurance about when the Science Centre would come into existence, but he would use whatever influence he had to secure that it would take on a noble setting. In reply to Lord Samuel's further inquiry regarding the policy the Government proposed to adopt to promote higher education of technologists, Lord Woolton said he could not hold out any hopes of an immediate and dramatic increase in the facilities for the training of higher technologists. After reviewing some of the applied research being carried out, Lord Woolton said he does not think British industry is making sufficient use of science or is properly staffed to do so. He is asking the Advisory Council on Scientific Policy to review the effectiveness of current arrangements for ensuring that the results of research make their contribution to the development of the British economy.

\section{Higher Technological Education}

LORD WoorTon continued with a statement to the effect that the Government is convinced that the improvement of facilities for higher technological education is a most important means of increasing productivity in industry, and that this can best be done by having at least one institution of university rank, devoted predcminantly to the teaching and study of the various forms of technology ; the practical possibilities of doing this are being explored. The Government recognizes the important contributions which technical colleges can make to higher technological education, and details of proposals for making improved financial assistance available for selected colleges and courses will be announced shortly by the Minister of Education. The Government does not propose, however, to establish a non-teaching awardmaking body under the title of Royal College of Technology-a much criticized proposal of the National Advisory Council on Education for Industry and Commerce which Mr. Attlee's Government had accepted in its White Paper of September 1951. The announcement regarding a technological institution of university rank was generally welcomed in the debate which followed, notably by Lord Hall and Lord Waverley, and by the Bishop of Coventry, who urged its establishment in an industrial centre, and Lord Webb-Johnson. Lord Waverley also urged the raising to university-level of a fow selected technical colleges and the linking of them with existing universities, while Lord Brabazon directed attention to the importance of a proper proportion of technicians to technologists. Lord Hankey reiterated his plea for a postgraduate college for scientists and technologists on the lines of the Imperial Defence College or the Administrative Staff College at Henley, and Lord Wavell and Lord Pakenham both raised the question of the general education of scientific men and the challenge this presents to the arts faculties of the universities.

\section{Nuclear Energy}

IN replying on the debate, Lord Cherwell dealt largely with the question of nuclear energy. In referring to the proposed technological university, he agreed that it is essential that it should have complete freedom and the same rights as other universities; but he also thought that there can be grave disadvantages in the freedom of scientific men to move between Government service, industry, and the universities. He said he is not anxious to encourage the movement to industry, and perhaps abroad, of men who have been dealing with very secret matters in the Government service. However understandable that attitude may be, something more may be needed if the reluctance of scientific workers to enter certain branches of Government service, at which the Advisory Council on Scientific Policy hinted in its recent report, is to be overcome. Lord Cherwell, however, in the main reviewed the prospects for nuclear energy. These, he held, are improving. There is hope of making what is called a breeder reactor, where the fast neutrons are allowed to react with enriched uranium or plutonium. By this method it might be possible to use something like 60 per cent of the uranium, and although considerable capital investment and long-term investigation will be involved, there are prospects of success within a reasonable number of years. He also said that there is a great advantage in making such nuclear bombs in place of the ordinary explosive bombs, in that if they are not used as bombs the materials can be used for this sort of reactor. Such developments, however, are limited by the availability of uranium and thorium. If we could use up the whole of the substance of these elements, considerably less than 100 tons of uranium or thorium a year would suffice in principle to provide all the power required in Great Britain.

\section{British Chemist's Visit to Austria and Italy}

Prof. John Read, professor of chemistry in the United College, University of St. Andrews, has recently returned from a lecturing tour in Austria and Italy. The itinerary lasted for about a month and was sponsored by the British Council. Prof. Read received a warm welcome from the Viennese 